\title{
Platelet-rich plasma for the treatment of lichen sclerosus
}

\author{
Beija K. Villalpando', Saranya P. Wyles ${ }^{2}$, Lauren A. Schaefer ${ }^{1}$, Katherine J. Bodiford ${ }^{3}$, Alison J. Bruce ${ }^{3}$ \\ ${ }^{1}$ Mayo Clinic Alix School of Medicine, Rochester, MN 55905, USA. \\ 2Department of Dermatology, Mayo Clinic, Rochester, MN 55901, USA. \\ ${ }^{3}$ Department of Dermatology, Mayo Clinic, Jacksonville, FL 32224, USA.
}

Correspondence to: Dr. Beija K. Villalpando, Mayo Clinic Alix School of Medicine, 200 1st St SW, Rochester, MN 55905, USA.

E-mail: villalpando.beija@mayo.edu

How to cite this article: Villalpando BK, Wyles SP, Schaefer LA, Bodiford KJ, Bruce AJ. Platelet-rich plasma for the treatment of lichen sclerosus. Plast Aesthet Res 2021;8:63. https://dx.doi.org/10.20517/2347-9264.2021.86

Received: 29 Jul 2021 First Decision: 22 Sep 2021 Revised:29 Sep 2021 Accepted: 4 Nov 2021 Published: 5 Dec 2021

Academic Editors: Wen-Guo Cui, Xiaoming Sun Copy Editor: Xi-Jun Chen Production Editor: Xi-Jun Chen

\begin{abstract}
Aim: Evaluate the clinical effectiveness of platelet-rich plasma as a treatment for lichen sclerosus.

Methods: A systematic review was performed. The electronic databases PubMed, Ovid MEDLINE ${ }^{\circledR}$, Web of Science, Cochrane, clinicaltrials.gov were used to identify case studies, case series, prospective uncontrolled, and randomized controlled studies published between 1946 and April 21, 2021. Six prospective uncontrolled studies, one randomized double-blind prospective study, and one case report were included.
\end{abstract}

Results: Platelet-rich plasma treatment was subjectively reported to improve quality of life, but objective measures demonstrating treatment efficacy were not observed. In addition, platelet-rich plasma preparation and administration between studies lacked standardization.

Conclusion: Platelet-rich plasma may be used for symptomatic adjuvant treatment of lichen sclerosus, though additional double-blind controlled studies with standardized platelet-rich plasma protocols are needed to better characterize the efficacy of platelet-rich plasma.

Keywords: Platelet-rich plasma, lichen sclerosus, vulvar lichen sclerosus, penile lichen sclerosus 


\section{INTRODUCTION}

Lichen sclerosus (LS) is a chronic inflammatory dermatosis characterized by ivory-white patches with surface wrinkling due to epidermal atrophy, which may display areas of hemorrhage or scar-like changes. LS commonly affects the anogenital region in males and females [Figures 1 and 2], although extragenital presentations also occur ${ }^{[1]}$. It is estimated to occur in 1 in 30 women and 1 in 900 pre-pubertal girls ${ }^{[2]}$. The etiology of LS has not yet been elucidated, though it is likely multifactorial and may include autoimmune, genetic, and hormonal causes, including estrogen deficiency ${ }^{[3,4]}$. Chronic trauma or irritation may be contributory $^{[5]}$.

There is currently no cure for LS. Accepted first-line treatment for LS is daily application of potent topical corticosteroids such as clobetasol propionate $0.05 \%$ ointment $^{[6,7]}$. Long-term topical steroid usage is potentially limited by compliance, side effects including further skin atrophy, steroid tachyphylaxis, and steroid-induced dermatitis ${ }^{[8]}$. For topical steroid treatment-resistant LS, alternate topical, intralesional and systemic therapies are utilized, i.e., topical calcineurin inhibitors, topical and systemic retinoids, intralesional corticosteroid injection, systemic immunosuppressants, and phototherapy. However, these second- and third-line therapies can be associated with poor initial response, resistance over time, and/or adverse drug effects. Further investigation regarding the efficacy of these treatments is warranted ${ }^{[9]}$. Currently, autologous platelet-rich plasma (PRP) is being explored as a treatment for LS.

Autologous PRP is obtained from the patient's own blood sample, which is drawn at the time of treatment. The blood draw occurs with the inclusion of an anticoagulant, such as citrate dextrose A, to prevent blood clotting during preparation. The patient's blood is then centrifuged, and the first spin is performed at constant acceleration to separate red and white blood cells from the remaining whole blood volume. The supernatant plasma containing platelets is then transferred into a sterile tube and again centrifuged at a higher speed, allowing for a concentrated platelet level to form in the lower tube [Figure 3]. The upper third of platelet-poor plasma is then removed, leaving the platelet-rich plasma to be administered ${ }^{[10]}$. Platelet-rich plasma contains a high level of growth factors, which are important for regenerative and therapeutic treatment. More specifically, platelet-derived growth factor (PDGF) and transforming growth factor- $\beta$ (TGF- $\beta$ ) stimulate fibroblast proliferation to increase collagen production ${ }^{[11]}$. Platelet-rich plasma increases the expression of matrix metalloproteinases which modulate remodeling ${ }^{[11]}$. Transforming growth factor alpha (TGF- $\alpha$ ) and epidermal growth factor (EGF) have been shown to modulate keratinocyte propagation and migration to thicken the epidermis ${ }^{[11]}$.

While PRP was initially used by hematologists in the 1970 s as a transfusion treatment for thrombocytopenia, the intrinsic regenerative properties of PRP have broadened its therapeutic use $\mathrm{e}^{[12]}$. In the 1980s, PRP first emerged from a strictly thrombocytopenic treatment to a peri-operative treatment for maxillofacial surgery ${ }^{[12]}$. However, PRP has been most extensively studied as a therapy for musculoskeletal injuries, including chronic tendinopathies, acute ligamentous injuries, muscle injuries, osteoarthritis, and bone healing for various types of fractures ${ }^{[1,13]}$. Since PRP's therapeutic inception, it has been utilized in many medical fields, such as dermatology, cardiovascular surgery, orthopedic surgery, pain management, and plastic surgery ${ }^{[13]}$. Specific to dermatological practice, PRP is being explored as a regenerative therapy for a variety of conditions, including wound healing, scar revision, alopecia, and $\mathrm{LS}^{[12]}$. The aim of this review is to identify, critically assess and synthesize available scientific evidence on the safety and clinical efficacy of PRP for the treatment of LS. To fulfill this aim, we have conducted a review of the scientific literature. 

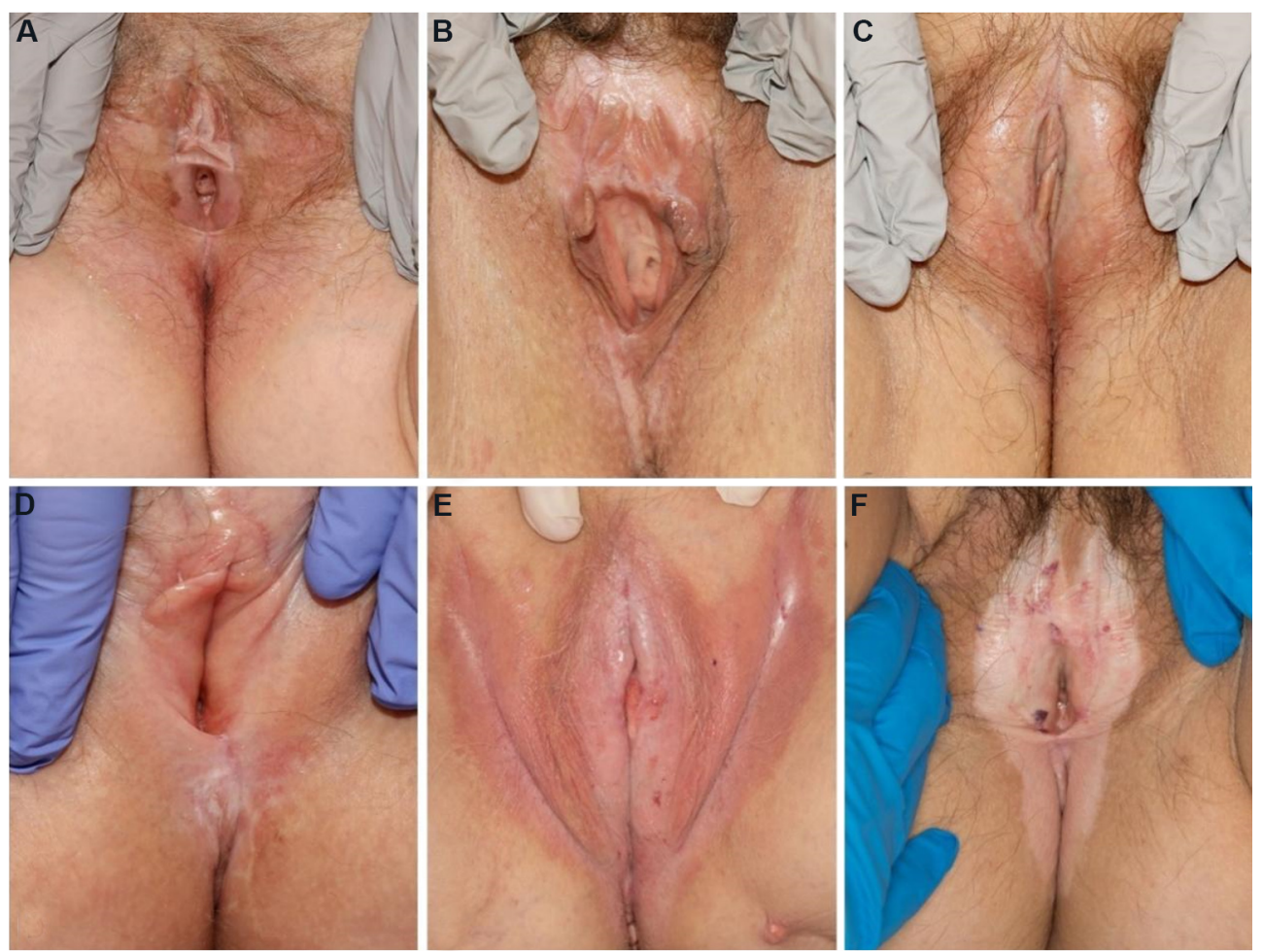

Figure 1. Patients with vulvar lichen sclerosus. (A) Shows a white atrophic patch involving the vulva and perianal skin in a figure-of-eight distribution with epidermal atrophy, agglutination of the bilateral labia minora, and superficial erosions present at the introitus. (B) Shows erythematous to hypopigmented vulvar patches with agglutination. (C) Shows atrophic white and focal erythematous patches without erosion or purpura. (D) Shows a white atrophic patch with minimal erythema in the vulva, agglutination with loss of the labia minora, and scarring of the clitoral hood. (E) Shows confluent erythematous patches involving the labia and the inguinal folds with whitish atrophic areas, minor fissures, and cracks. (F) Shows hypopigmentation in a figure-of-eight distribution involving the vulva and perianal area with scattered areas of hemorrhage. (By permission of Mayo Foundation for Medical Education and Research. All rights reserved.).
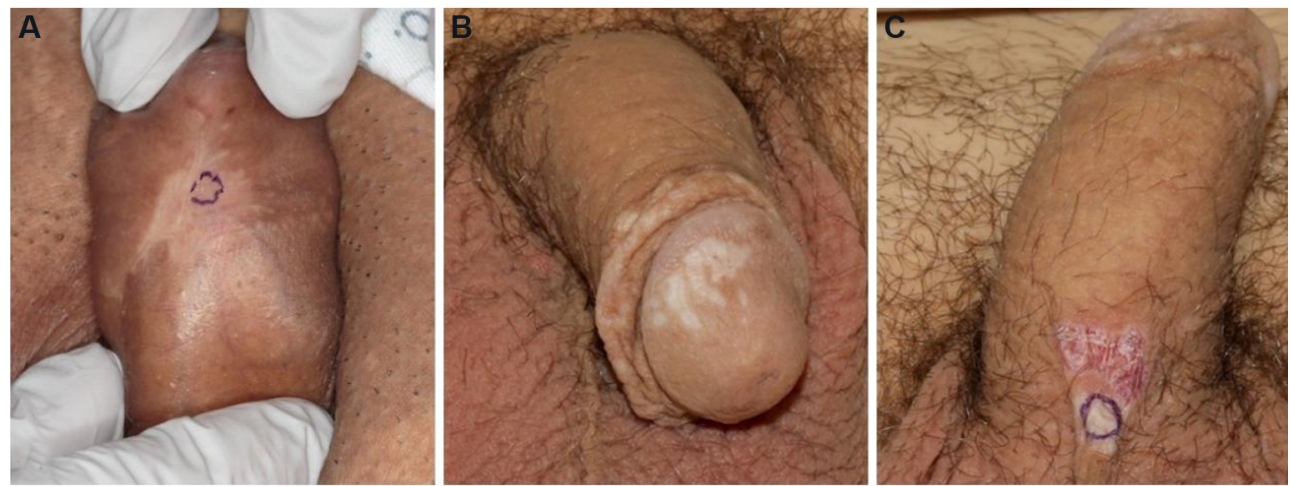

Figure 2. Patients with penile lichen sclerosus. (A) Shows a hypopigmented, atrophic, slightly geometrically shaped patch involving the ventral penis. There is a purple biopsy mark site present. (B) Shows numerous scattered white atrophic macules coalescing to patches. (C) Shows a white atrophic patch with epidermal wrinkling and hemorrhage on the ventral base of the penis. There is a purple biopsy mark site present. (By permission of Mayo Foundation for Medical Education and Research. All rights reserved.).

\section{METHODS}

An experienced information specialist developed and conducted an extensive search of Ovid MEDLINE ${ }^{\bullet}$ 1946 to Present and Epub Ahead of Print, In-Process \& Other Non-Indexed Citations and Ovid MEDLINE ${ }^{\bullet}$ 

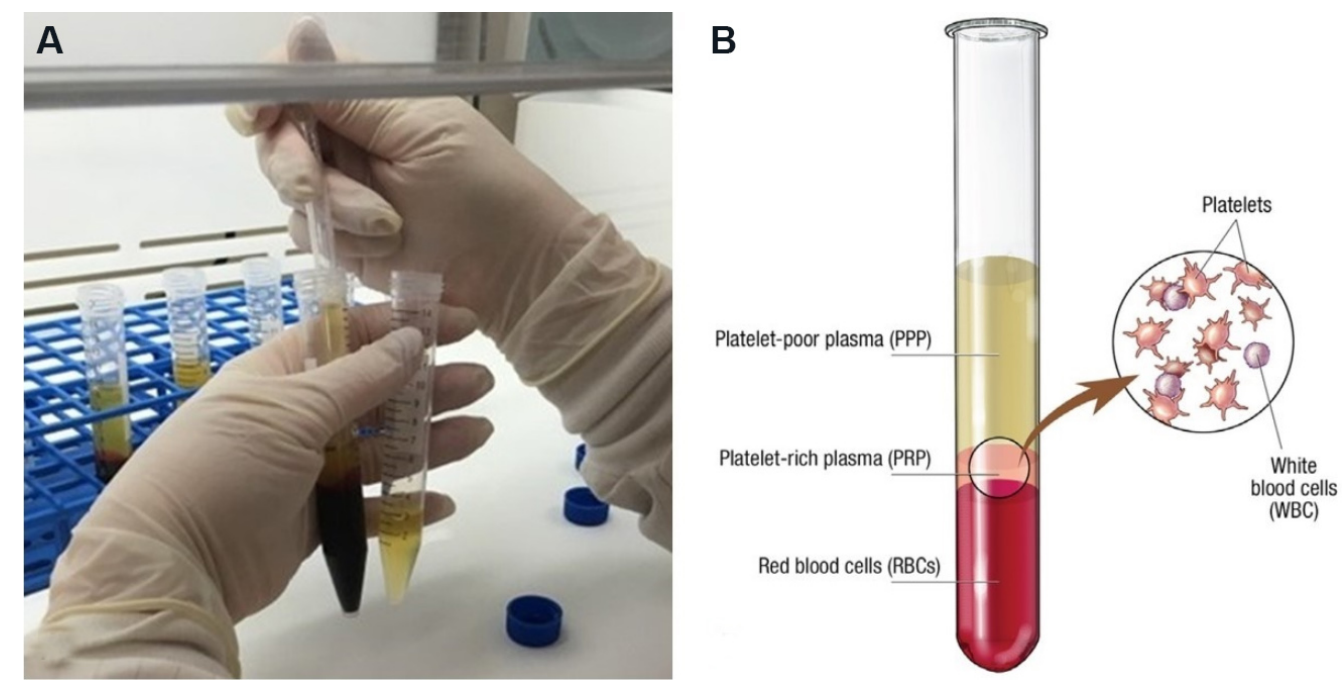

Figure 3. PRP processing. (A) Shows the removal of the upper portion of plasma from each conical tube after centrifugation. (B) Shows the separation of red blood cells, platelet-rich plasma, and platelet-poor plasma following centrifugation. (By permission of Mayo Foundation for Medical Education and Research. All rights reserved.). PRP: Platelet-rich plasma.

Daily, Ovid MEDLINE ${ }^{\bullet}$ Daily Update, EBM Reviews - Cochrane Central Register of Controlled Trials March 2021, EBM Reviews - Cochrane Database of Systematic Reviews 2005 to April 21, 2021, Embase 1974 to 2021 April 21, PubMed 1946 to 2021 April 21, Web of Science 1975 to 2021 April 21, and ClinicalTrials.gov through 2021 April 21 to identify case studies, case series, prospective uncontrolled, and randomized controlled studies published between 1946 and April 21, 2021. The search strategy combined the terms "Lichen Sclerosus et Atrophicus" OR "lichen sclerosus" OR "lichen scleroses" AND "Platelet-Rich Plasma" OR "platelet rich plasma" OR "thrombocyte-rich plasma” OR "thrombocyte rich plasma”. Works were limited to the English language and excluded animal studies, guidelines, protocols, and review articles. Potentially eligible titles were identified using controlled vocabulary in tandem with keywords. The search strategy was peer-reviewed prior to execution.

\section{RESULTS}

The results of the literature search and study selection process are shown in Figure 4. The main characteristics of selected studies are summarized in Table 1. All of them were published in English between 2016 and 2020. Study size was highly variable, ranging from 1 to 94 participant(s). Eight total studies included 6 prospective uncontrolled studies, 1 randomized double-blind prospective study, and 1 case report. Level of evidence ranged from level III to level V. Participants ranged from age 21 to 88 years old. Five studies evaluated only female participants; one study evaluated only male participants; three studies included both female and male participants. Types of LS evaluated include vulvovaginal, vulvar, and penile. Lichen sclerosus diagnosis was established with histopathology (H\&E) for 6 studies; histopathology (H\&E) combined with colposcopy for 1 study, and not reported for the remaining studies. Four studies evaluated participants who failed prior treatment, including topical steroids, emollients, and/or circumcision.

The source of PRP varied between studies and is summarized in Table 2. PRP spin approach, spin duration, and activator were not reported for the majority of studies; only 1 study reported a double-spin approach, 6and 12-min spin durations, with calcium chloride as a PRP activator. Four studies reported local anesthesia use prior to PRP application, while the remaining studies did not report if anesthesia was utilized. Seven of the eight studies reported the PRP amount applied per treatment, which ranged from 2-10 $\mathrm{mL}$. One study 
Table 1. Study demographics

\begin{tabular}{|c|c|c|c|c|c|c|c|c|c|}
\hline Authors & $\begin{array}{l}\text { Type of } \\
\text { study }\end{array}$ & $\begin{array}{l}\text { Level of } \\
\text { evidence }\end{array}$ & $\begin{array}{l}n \\
\text { (females:males) }\end{array}$ & $\begin{array}{l}\text { Age } \\
\text { (year) }\end{array}$ & Type of LS & LS diagnosis & $\begin{array}{l}\text { Prior } \\
\text { treatment }\end{array}$ & Outcomes & $\begin{array}{l}\text { Follow-up } \\
\text { (months) }\end{array}$ \\
\hline $\begin{array}{l}\text { Behnia-Willison et al. }{ }^{[14]} \\
(2016)\end{array}$ & PU & IV & 28 (females) & $22-88$ & Vulvovaginal & $\begin{array}{l}\text { Colposcopy } \pm \\
\text { histopathology }\end{array}$ & Topical steroids & $\begin{array}{l}\text { 8/28 (28.5\%) LS skin lesions resolved } \\
15 / 28(53.6 \%) \text { LS full symptoms }{ }^{\#} \text { relief } \\
13 / 28(46.4 \%) \text { LS partial symptoms } \text { relief }^{\#}\end{array}$ & 12 \\
\hline Casabona et al. ${ }^{[15]}$ (2017) & PU & IV & 45 (males) & $\begin{array}{l}42.96 \pm \\
11.32\end{array}$ & Penile & NR & $\begin{array}{l}\text { Topical steroids } \\
\pm \text { circumcision }\end{array}$ & $\begin{array}{l}42 / 45(93.3 \%) \text { resolved phimosis and } 44 / 45(97.7 \%) \\
\text { resolved meatus stenosis } \\
45 / 45(100 \%) \text { patients had no atrophy, splitting and } \\
\text { inflammation } \\
\text { Patients reported improved IGA quality of life }(P<0.001) \\
\text { and DLQI }(P<0.001)\end{array}$ & $17.6 \pm 5.6$ \\
\hline Goldstein et al. ${ }^{[16]}$ (2017) & PU & IV & 12 (females) & NR & Vulvar & Histopathology & NR & $\begin{array}{l}7 / 12(58.3 \%) \text { decreased inflammation in post-treatment } \\
\text { skin biopsy } \\
5 / 12(41.7 \%) \text { no change or minimal increase in post- } \\
\text { treatment skin biopsy }\end{array}$ & NR \\
\hline Franic et al. ${ }^{[17]}$ (2018) & $\mathrm{CR}$ & v & 1 (females) & 38 & Vulvar & Histopathology & $\begin{array}{l}\text { Topical steroids } \\
\text { and emollients }\end{array}$ & $\begin{array}{l}\text { Patient reported improved ICIQ-VS for quality of life and } \\
\text { sexual matters } \\
\text { Post-treatment FSFI improved from } 3.6 \text { to } 32.6 \text { (range } 2 \text { to } \\
\text { 36) }\end{array}$ & 2 \\
\hline Goldstein et al. ${ }^{[18]}$ (2019) & RDBP & III & $\begin{array}{l}29 \text { (females) } \\
10 \text { placebo, } 19 \text { PRP }\end{array}$ & 52.6 & Vulvar & Histopathology & NR & $\begin{array}{l}\text { None of the observed outcomes were statistically } \\
\text { significant }\end{array}$ & NR \\
\hline Posey et al. ${ }^{[19]}$ (2019) & PU & IV & 38 (females) & NR & Vulvar & Histopathology & NR & $\begin{array}{l}\text { None of the observed outcomes were statistically } \\
\text { significant }\end{array}$ & NR \\
\hline Tedesco et al. ${ }^{[20]}$ (2019) & PU & IV & $\begin{array}{l}31 \text { ( } 18 \text { females: } 13 \\
\text { males) }\end{array}$ & NR & $\begin{array}{l}\text { Vulvar and } \\
\text { penile }\end{array}$ & Histopathology & Topical steroids & $\begin{array}{l}\text { 19/31 (62\%) reported symptom }{ }^{\#} \text { relief } \\
11 / 31(35 \%) \text { reported stable symptoms }{ }^{\#} \\
1 / 31(3 \%) \text { reported symptom }{ }^{\#} \text { worsening } \\
76.4 \% \text { of females reported improvement compared to } \\
47.5 \% \text { of males }(P<0.05)\end{array}$ & 12 \\
\hline Tedesco et al. ${ }^{[21]}(2020)$ & PU & IV & $\begin{array}{l}94 \text { ( } 51 \text { females: } 43 \\
\text { males) }\end{array}$ & $21-83$ & $\begin{array}{l}\text { Vulvar and } \\
\text { penile }\end{array}$ & Histopathology & NR & $\begin{array}{l}\text { Patients reported improvement in itch ( } 58.8 \%: 27.7 \% \\
\text { females:males), burning ( } 35.3 \%: 21 \% \text { females:males), pain } \\
(25.5 \%: 0 \% \text { females:males), and dyspareunia }(0 \%: 23.3 \% \\
\text { females:males) } \\
\text { Patients reported improved DLQI ( } P<0.0001)\end{array}$ & 6 \\
\hline
\end{tabular}

"\#ymptoms: itch (requiring steroid treatment), soreness, discomfort, burning and/or dyspareunia. PU: Prospective uncontrolled; RP: randomized prospective; CS: case series; CR: case report; RDBP: randomized double-blind prospective; NR: not recorded; FSFI: Female Sexual Function Index evaluated desire, arousal, lubrication, orgasm, satisfaction, and pain; DLQI: Dermatology Life Quality Index evaluated itch, pain, and feelings of embarrassment and self-consciousness, problems with therapy, and interference from a skin disease in daily activities, relationships, and sex life; IGA: Investigator's Global Assessment evaluated the extent of disease involvement based on erythema, infiltration, lichenification, and excoriation; ICIQ-VS: Incontinence Questionnaire-Vaginal Symptoms.

doubled the volume in the second dose received, while 6 studies maintained the same PRP dose between treatments. One study did not report the PRP amount used. Platelet-rich plasma delivery methods varied between studies but included subdermal and intradermal injections into the affected areas. Of the seven 
Table 2. Platelet-rich plasma preparation and application

\begin{tabular}{|c|c|c|c|c|c|c|c|c|}
\hline Authors & $\begin{array}{l}\text { PRP spin } \\
\text { approach }\end{array}$ & Company & $\begin{array}{l}\text { PRP spin } \\
\text { duration }\end{array}$ & $\begin{array}{l}\text { PRP } \\
\text { activator }\end{array}$ & Anesthesia & $\begin{array}{l}\text { PRP amount } \\
\text { applied }\end{array}$ & PRP application method & $\begin{array}{l}\text { PRP application } \\
\text { frequency }\end{array}$ \\
\hline $\begin{array}{l}\text { Behnia-Willison et al. }{ }^{[14]} \\
\text { (2016) }\end{array}$ & NR & $\begin{array}{l}\text { Regens Lab, New York, } \\
\text { NY }\end{array}$ & NR & NR & $\begin{array}{l}\text { Local } \\
\text { anesthesia }\end{array}$ & NR & $\begin{array}{l}\text { Affected areas of the external genitalia, } \\
\text { including the labia majora, labia minora, clitoris, } \\
\text { and clitoral hood was injected using a } 27 \text {-gauge } \\
\text { needle in a fanning motion }\end{array}$ & $\begin{array}{l}\text { Patients received } 3 \\
\text { treatments every } 4 \text { to } 6 \\
\text { weeks and again at } 12 \\
\text { months }\end{array}$ \\
\hline Casabona et al. ${ }^{[15]}$ (2017) & Double & NR & $\begin{array}{l}6 \text { min at } 1000 \\
\text { rpm then } 12 \mathrm{~min} \\
\text { at } 3000 \mathrm{rpm}\end{array}$ & $\mathrm{CaCl}_{2}$ & $\begin{array}{l}\text { Topical and } \\
\text { local anesthesia }\end{array}$ & $2 \mathrm{~mL}$ per treatment & $\begin{array}{l}\text { PRP was applied to ulcerated areas with micro- } \\
\text { wheals technique, while subcutaneous and } \\
\text { submucosal micro-tunneling technique was } \\
\text { performed in sclerotic/fibrotic areas }\end{array}$ & $\begin{array}{l}\text { Patients received a range } \\
\text { of 2-10 treatments } \\
\text { (unspecified interval) }\end{array}$ \\
\hline Goldstein et al. ${ }^{[16]}$ (2017) & NR & $\begin{array}{l}\text { Magellan }{ }^{\circledR} \text { Autologous } \\
\text { Platelet Separator } \\
\text { System, Hopkinton, MA }\end{array}$ & NR & NR & NR & $5 \mathrm{~mL}$ per treatment & $\begin{array}{l}\text { Autologous PRP was applied subdermally and } \\
\text { intradermally }\end{array}$ & $\begin{array}{l}\text { Patients received } 2 \\
\text { treatments separated by } \\
6 \text { weeks }\end{array}$ \\
\hline Franic et al. ${ }^{[17]}(2018)$ & NR & $\begin{array}{l}\text { Cellular Matrix RegenKit }{ }^{\circledast} \\
\text { Regen Lab SA } \\
\text { Lausanne, Switzerland }\end{array}$ & NR & NR & $\begin{array}{l}\text { Local } \\
\text { anesthesia }\end{array}$ & $\begin{array}{l}4 \mathrm{~mL} \text { with first } \\
\text { procedure, } 8 \mathrm{~mL} \\
\text { with second } \\
\text { procedure }\end{array}$ & $\begin{array}{l}\text { Autologous PRP was injected subdermally in } \\
\text { affected regions }\end{array}$ & $\begin{array}{l}\text { Patients received } 2 \\
\text { treatments separated by } \\
2 \text { months }\end{array}$ \\
\hline Goldstein et al. ${ }^{[18]}$ (2019) & NR & $\begin{array}{l}\text { Magellan }{ }^{\circledR} \text { Autologous } \\
\text { Platelet Separator } \\
\text { System, Hopkinton, MA }\end{array}$ & NR & NR & NR & $5 \mathrm{~mL}$ per treatment & $\begin{array}{l}\text { PRP was injected sub-dermally and intra- } \\
\text { dermally to affected areas }\end{array}$ & $\begin{array}{l}\text { Patients received } 2 \\
\text { treatments separated by } \\
6 \text { weeks }\end{array}$ \\
\hline Posey et al. ${ }^{[19]}$ (2019) & NR & NR & NR & NR & NR & $\begin{array}{l}10 \mathrm{~mL} \text { per } \\
\text { treatment }\end{array}$ & PRP was injected into affected areas & NR \\
\hline Tedesco et al. ${ }^{[20]}$ (2019) & NR & $\begin{array}{l}\text { SELPHYL®, Cascade } \\
\text { Medical Enterprises, } \\
\text { Plymouth, UK }\end{array}$ & NR & NR & NR & $4 \mathrm{~mL}$ per treatment & $\begin{array}{l}\text { In females, PRP was injected into posterior } \\
\text { fourchette ( } 2 \text { wheals), hood ( } 2 \text { wheals) and into } \\
\text { the right and left labia ( } 2 \text { wheals) } \\
\text { In males, } 4 \mathrm{~mL} \text { was injected into the four } \\
\text { cardinal points of the area affected with micro- } \\
\text { wheals technique }\end{array}$ & $\begin{array}{l}\text { Patients received } 1 \\
\text { treatment every } 15 \text { days } \\
\text { for } 3 \text { total treatments }\end{array}$ \\
\hline Tedesco et al. ${ }^{[21]}(2020)$ & NR & $\begin{array}{l}\text { C.Punt-Biomed System } \\
\text { and SELPHYL }{ }^{\circledR}, \text { Cascade } \\
\text { Medical Enterprises, } \\
\text { Plymouth, UK }\end{array}$ & NR & NR & $\begin{array}{l}\text { Topical } \\
\text { anesthesia }\end{array}$ & $4 \mathrm{~mL}$ per treatment & $\begin{array}{l}\text { PRP was injected into the posterior fourchette } \\
\text { ( } 2 \text { wheals), into the hood ( } 2 \text { wheals), and into } \\
\text { labia minora ( } 2 \text { wheals) }\end{array}$ & $\begin{array}{l}\text { Patients received } 1 \\
\text { treatment every } 15 \text { days } \\
\text { for } 3 \text { total treatments }\end{array}$ \\
\hline
\end{tabular}

NR: Not recorded; PRP: platelet-rich plasma.

studies that reported the number of treatments, participants received between 2 to 10 total treatments. Six studies reported standard treatment schedules among participants with an average of 2.98 treatments per participant. Follow-up time ranged from 2 to 23.2 months with an average follow-up time of 9.9 months; three studies did not provide follow-up duration. 


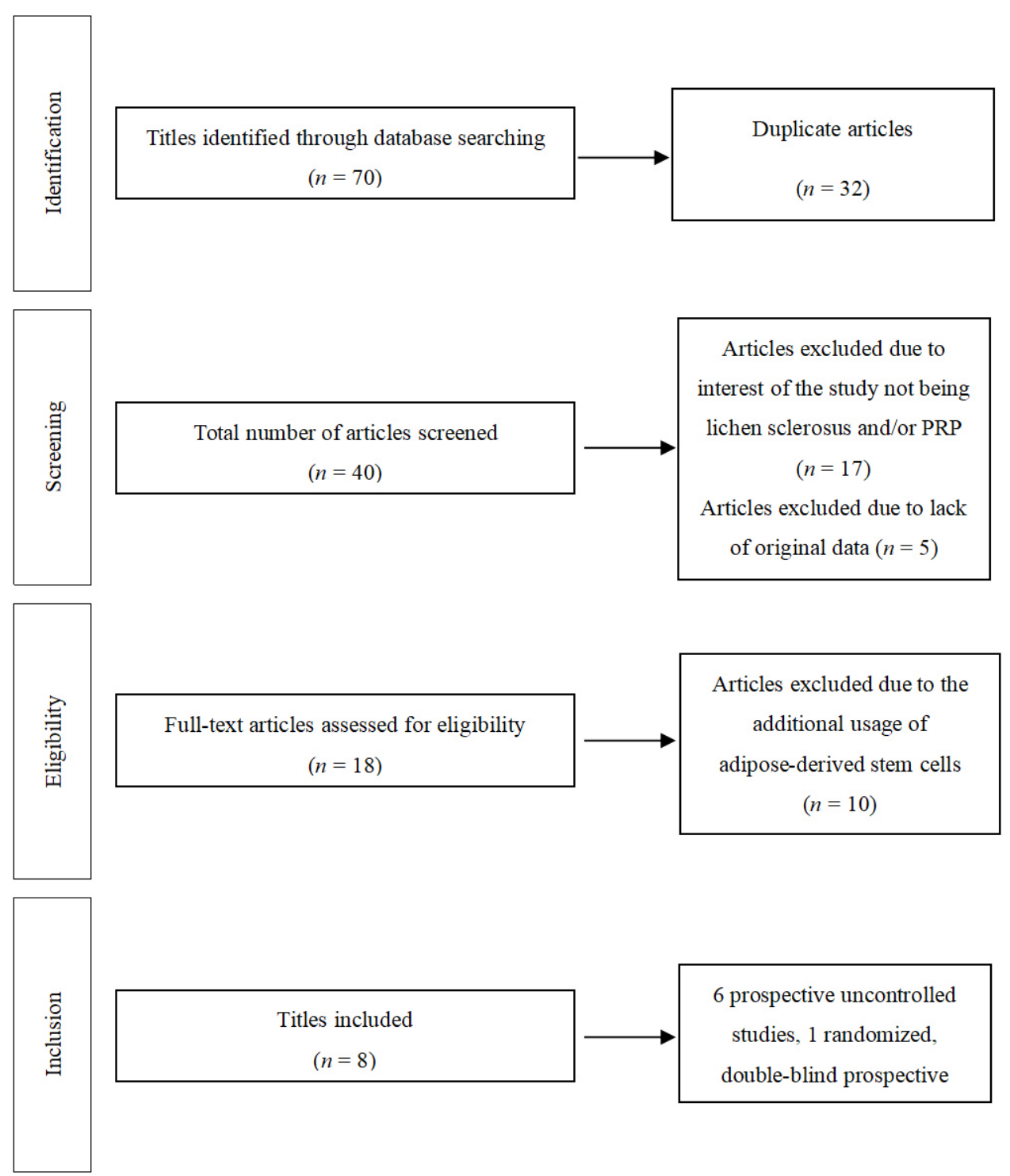

Figure 4. Flow diagram summarizing literature search, screening, and review. PRP: Platelet-rich plasma.

Six of the eight studies used patient questionnaires to assess the effect of PRP on LS symptom relief and/or quality of life. Three studies found that PRP treatment led to full or partial LS symptom relief. By using validated questionnaires, 3 studies reported that PRP improved patient quality of life. Posey et al ${ }^{[19]}$ reported the utilization of a patient questionnaire, but none of the observed outcomes were clinically significant. Following PRP treatment, Behnia-Willison et al. ${ }^{[14]}$ used colposcopy to evaluate vulvovaginal lesions and reported $28 \%$ of LS lesions were completely resolved. Two studies compared pre- and post-treatment histology.

\section{DISCUSSION}

Therapies rooted in regenerative medicine, such as PRP, seek to repair damaged tissues and restore normal function via stimulating the body's own regenerative capacity. Platelet-rich plasma consists of various fundamental proteins, which contribute to wound healing, including PDGF, TGF- $\beta$, vascular endothelial growth factor, EGF, and adhesive proteins-fibrin, fibronectin, and vitronectin ${ }^{[2]}$. These factors promote 
angiogenesis, mitogenesis, macrophage activation, vasculogenesis, proliferation, differentiation, and regulation of inflammatory processes ${ }^{[23]}$.

Previous studies reported that PRP administration improved quality of life, as well as clinical and histological parameters of $\mathrm{LS}^{[23]}$. However, the quality of the evidence is low. Confidence in the literature is limited due to lack of control and comparison groups, placebo groups, and random assignments. Goldstein et al. ${ }^{[18]}$ was the only double-blinded controlled study to assess the efficacy of LS, and this study found no benefit of PRP compared to placebo. In addition, the literature is further limited by the lack of standardization of PRP preparation, quantity, concentration, treatment frequency, and delivery method. Continuing, the literature illustrated a wide variety of outcome measurements with no universally accepted intervention that objectively illustrates PRP benefit in the treatment of LS.

Indeed, LS is a debilitating disease that left untreated causes scarring, discomfort, dyspareunia, decreased quality of life, and potentially increases the risk of cancer development. The main goals for the treatment and management of LS are to provide symptomatic relief, minimize urinary and/or sexual dysfunction and prevent malignant transformation ${ }^{[24]}$. It has not been proven whether early steroid treatment of LS mitigates the risk of malignant transformation, although a recent retrospective review of 301 male patients treated with topical steroids found no progression to penile squamous cell carcinoma ${ }^{[25]}$. In addition, a longitudinal prospective cohort study found that long-term topical steroid use decreased scarring and the incidence of vulvar squamous cell carcinoma in women with vulvar $\mathrm{LS}^{[8]}$.

Future directions for LS management should focus on expanding treatment options to improve quality of life for affected patients and help prevent malignant transformation. Platelet-rich plasma may prove to be a valuable treatment intervention. However, the variability in preparation and administration needs to be addressed in order to allow comparative assessment. In addition to PRP, regenerative therapies for LS also include adipose-derived stem cells, which are postulated to exert their effect through paracrine release of growth factors ${ }^{[26]}$. Limited studies have evaluated the efficacy of fat grafting in the treatment of severe vulvar LS with varying improvement in mucocutaneous elasticity and resolution of symptoms, i.e., pruritus and dyspareunia ${ }^{[27]}$.

The rise in such regenerative therapies warrants further studies to standardize both cellular and acellular clinical adjuvants for wound healing in inflammatory skin conditions, such as LS. Platelet-rich plasma may have a role as a supporting treatment in selected cases of patients with severe LS who do not respond to first-line therapy, in severe cases where the anatomical impairment impedes sexual function and patient quality of life or where other therapies are poorly tolerated or contraindicated.

\section{DECLARATIONS}

\section{Authors' contributions}

Performed literature review, drafted manuscript, acted as the corresponding author: Villalpando BK

Performed literature review, drafted manuscript, provided expert insight: Wyles SP

Performed literature review and drafted manuscript: Schaefer LA

Drafted manuscript and provided expert insight: Bodiford KJ, Bruce AJ

\section{Availability of data and materials}

Not applicable. 


\section{Financial support and sponsorship}

This work was supported by the National Institute of General Medical Science NIH T32 GM6584.

\section{Conflicts of interest}

All authors declared that there are no conflicts of interest.

\section{Ethical approval and consent to participate}

Not applicable.

\section{Consent for publication}

Patient consent was obtained for representative LS photographs.

\section{Copyright}

(c) The Author(s) 2021.

\section{REFERENCES}

1. Röcken M, Ghoreschi K. Morphea and lichen sclerosus. In: Bolognia JL, Schaffer JV, Cerroni L, editors. Dermatology. China: Elsevier Limited; 2018. p. 707-21.

2. Marfatia Y, Surani A, Baxi R. Genital lichen sclerosus et atrophicus in females: an update. Indian J Sex Transm Dis AIDS 2019;40:612. DOI PubMed PMC

3. Sherman V, McPherson T, Baldo M, Salim A, Gao XH, Wojnarowska F. The high rate of familial lichen sclerosus suggests a genetic contribution: an observational cohort study. J Eur Acad Dermatol Venereol 2010;24:1031-4. DOI PubMed

4. Nair PA. Dermatosis associated with menopause. J Midlife Health 2014;5:168-75. DOI PubMed PMC

5. Hofer MD, Meeks JJ, Mehdiratta N, Granieri MA, Cashy J, Gonzalez CM. Lichen sclerosus in men is associated with elevated body mass index, diabetes mellitus, coronary artery disease and smoking. World J Urol 2014;32:105-8. DOI PubMed

6. Neill SM, Lewis FM, Tatnall FM, Cox NH; British Association of Dermatologists. British Association of Dermatologists' guidelines for the management of lichen sclerosus 2010. Br J Dermatol 2010;163:672-82. DOI PubMed

7. Dalziel KL, Millard PR, Wojnarowska F. The treatment of vulval lichen sclerosus with a very potent topical steroid (clobetasol propionate 0.05\%) cream. Br J Dermatol 1991;124:461-4. DOI PubMed

8. Lee A, Bradford J, Fischer G. Long-term management of adult vulvar lichen sclerosus: a prospective cohort study of 507 women. JAMA Dermatol 2015;151:1061-7. DOI PubMed

9. Kirtschig G, Becker K, Günthert A, et al. Evidence-based (S3) Guideline on (anogenital) Lichen sclerosus. J Eur Acad Dermatol Venereol 2015;29:e1-43. DOI PubMed

10. Dhurat R, Sukesh M. Principles and methods of preparation of platelet-rich plasma: a review and author's perspective. J Cutan Aesthet Surg 2014;7:189-97. DOI PubMed PMC

11. Chicharro-Alcántara D, Rubio-Zaragoza M, Damiá-Giménez E, et al. Platelet rich plasma: new insights for cutaneous wound healing management. J Funct Biomater 2018;9:10. DOI PubMed PMC

12. Alves R, Grimalt R. A review of platelet-rich plasma: history, biology, mechanism of action, and classification. Skin Appendage Disord 2018;4:18-24. DOI PubMed PMC

13. Everts P, Onishi K, Jayaram P, Lana JF, Mautner K. Platelet-rich plasma: new performance understandings and therapeutic considerations in 2020. Int J Mol Sci 2020;21:7794. DOI PubMed PMC

14. Behnia-Willison F, Pour NR, Mohamadi B, et al. Use of platelet-rich plasma for vulvovaginal autoimmune conditions like lichen sclerosus. Plast Reconstr Surg Glob Open 2016;4:e1124. DOI PubMed PMC

15. Casabona F, Gambelli I, Casabona F, Santi P, Santori G, Baldelli I. Autologous platelet-rich plasma (PRP) in chronic penile lichen sclerosus: the impact on tissue repair and patient quality of life. Int Urol Nephrol 2017;49:573-80. DOI PubMed

16. Goldstein AT, King M, Runels C, Gloth M, Pfau R. Intradermal injection of autologous platelet-rich plasma for the treatment of vulvar lichen sclerosus. J Am Acad Dermatol 2017;76:158-60. DOI PubMed

17. Franic D, Iternička Z, Franić-Ivanišević M. Platelet-rich plasma (PRP) for the treatment of vulvar lichen sclerosus in a premenopausal woman: a case report. Case Rep Womens Health 2018;18:e00062. DOI PubMed PMC

18. Goldstein AT, Mitchell L, Govind V, Heller D. A randomized double-blind placebo-controlled trial of autologous platelet-rich plasma intradermal injections for the treatment of vulvar lichen sclerosus. J Am Acad Dermatol 2019;80:1788-9. DOI PubMed

19. Posey LK. Evaluating in office surgery followed by platelet rich plasma to treat lichen sclerosus. Abstracts. J Low Genit Tract Dis 2019;23:S37-81. DOI

20. Tedesco M, Pranteda G, Chichierchia G, et al. The use of PRP (platelet-rich plasma) in patients affected by genital lichen sclerosus: clinical analysis and results. J Eur Acad Dermatol Venereol 2019;33:e58-9. DOI PubMed

21. Tedesco M, Garelli V, Bellei B, et al. Platelet-rich plasma for genital lichen sclerosus: analysis and results of 94 patients. Are there gender-related differences in symptoms and therapeutic response to PRP? J Dermatolog Treat 2020:1-5. DOI PubMed 
22. Jain NK, Gulati M. Platelet-rich plasma: a healing virtuoso. Blood Res 2016;51:3-5. DOI PubMed PMC

23. Eshtiaghi P, Sadownik LA. Fact or fiction? J Low Genit Tract Dis 2019;23:65-70. DOI PubMed

24. Kwok R, Shah TT, Minhas S. Recent advances in understanding and managing Lichen Sclerosus. F1000Res 2020;9:369. DOI PubMed PMC

25. Kravvas G, Shim TN, Doiron PR, et al. The diagnosis and management of male genital lichen sclerosus: a retrospective review of 301 patients. J Eur Acad Dermatol Venereol 2018;32:91-5. DOI PubMed

26. Rehman J, Traktuev D, Li J, et al. Secretion of angiogenic and antiapoptotic factors by human adipose stromal cells. Circulation 2004;109:1292-8. DOI PubMed

27. Boero V, Brambilla M, Sipio E, et al. Vulvar lichen sclerosus: a new regenerative approach through fat grafting. Gynecol Oncol 2015;139:471-5. DOI PubMed 